\title{
A ÉTICA NO COTIDIANO E AS DIFICULDADES DA SAÚDE PÚBLICA
}

Juliana Da SILVA, Yolanda Flores e SILVA

Sentindo os problemas da saúde pública brasileira, procuramos dentro da ética do cotidiano, argumentos para uma discussão teórica. Esta dissertação teve por objetivo analisar como a ética do cotidiano está presente na legislação do SUS. Foi utilizada a metodologia qualitativa para conhecer o universo de nosso trabalho que foi documental e bibliográfico. Desenvolvemos uma análise acerca da ética e do cotidiano usando como referencial trabalhos da filósofa húngara Agnes Heller. Selecionamos material bibliográfico com a ajuda de profissionais especialistas na temática estudada (ética e saúde). Este material incluiu a legislação do SUS, que continham aspectos da ética cotidiana, acrescida de livros e periódicos da área da saúde considerados relevantes. A técnica escolhida para análise de dados envolve a análise de discurso e conteúdo, utilizando-se como referência metodológica uma adaptação do modelo de cooperação textual de Umberto Eco. Ao final, um mapeamento da legislação e demais bibliografias sobre o SUS foi efetuado. Vimos que, na maioria das vezes, quando se fala de ética, ela aparece categorizada e num capítulo à parte, visualizamos que a ética cotidiana é parte transversal do discurso do SUS, porém de maneira implícita. Observamos que os discursos refletem o que existe no cotidiano da saúde e que a ética do cotidiano norteia pressupostos e recomendações quanto as práticas de atuação no SUS.

Palavras-chave: Ética; SUS; Saúde Pública. 